\title{
СПЕЦИФІКА ІНДИВІДУАЛЬНОГО АВТОРСЬКОГО БАЧЕННЯ ПРОТИСТАВЛЕННЯ «СВОЇ - ЧУЖІ» (ЗА ТВОРАМИ М. МАТІОС І Д. РУБІНОї)
}

\author{
Вікторія ЯКИМОВИЧ
}

\author{
викладач Кременецького педагогічного коледжу \\ Кременецької обласної гуманітарно-педагогічної академії ім. Тараса Шевченка (УКРАїНА) \\ e-mail: vikayakym@gmail.com \\ UDC: 82.00
}

DOI 10.25128/2304-1222.20.50.11

\begin{abstract}
In this article prose of the Ukrainian writer M. Matios and Russian-Israeli author D. Rubina became the subject of special scientific exploration with the help of imagological discourse. M. Matios and D. Rubina interpret the relationship of «own» and «other» through their own vision, personal thought, worldview, creative mind and experience of knowing the world. Their prose is linked to important life themes, and prototypes of their characters are often real people. Unlike M. Matios, D. Rubina is constantly in different national cultural areas, experiencing the influence of multicultural environments and intercultural relations. Therefore, as a Russian-Israeli writer, she visualizes the idea of another people, different cultures, using national markers. Features of national character, including Jewish and Uzbek, which are related to its origin and place of birth, are traced in the analyzed works of the author. M. Matios' work is linked to the Ukrainian national component and is distinguished by its national identity and folklore. Comparison and analysis of the linguistic aspect of the writers' works showed that in order to express the speech of the characters, M. Matios uses dialectic words, folklore and artistic word combinations, and D. Rubin uses jargon, slangs, obscene vocabulary.
\end{abstract}

Key words: imagological discourse, «own», «other», «foreign», national images, national peculiarities, stylistic devices.

У статті вперше проза української письменниці М. Матіос і російсько-ізраїльської авторки Д. Рубіної стала предметом спеціальної наукової розвідки крізь призму імагологічного дискурсу. М. Матіос і Д. Рубіна інтерпретують відносини «свого» та «чужого» через власне бачення, особисту думку, світогляд, творчий задум і досвід пізнання світу. Їхня творчість пов'язана з важливими життєвими темами, а прототипи їхніх персонажів - часто реальні люди. На відміну від М. Матіос, Д. Рубіна постійно перебуває в різних національних культурних ареалах, відчуває вплив полікультурних середовищ і міжкультурних відносин. Тому вона як російсько-ізраїльська письменниця візуалізує уявлення про інший народ, іншу культуру, використовуючи національні маркери. Особливості національних характерів, зокрема єврейського та узбецького, що пов'язано з іiі походженням і місцем народження, прослідковуються у проаналізованих творах авторки. Відмінно від Д. Рубіної, творчість M. Матіос пов'язана 3 українським національним компонентом i вирізняється національною самобутністю та фольклористичністю. Зіставлення та аналіз мовного аспекту текстів творів письменниць показав, що 3 метою увиразнення мовлення персонажів М. Матіос використовує діалектизми, просторічні слова, фольклорні і художні тропи, а Д. Рубіна - жаргонізми, сленгізми, обсцентну лексику.

Ключові слова: імагологічний дискурс, «свій», «чужий», національний колорит, мовні засоби.

W artykule przedmiotem specjalnych badań naukowych za pomocą dyskursu wyobrażeniowego stała się proza ukraińskiej pisarki M. Matios i rosyjsko-izraelskiej pisarki D. Rubiny. M. Matios i D. Rubina interpretują relację „własny” i ,inny” poprzez własną wizję, osobistą myśl, światopogląd, twórczy umysł i doświadczenie poznawania świata. Ich proza jest powiązana $\mathrm{z}$ ważnymi tematami życiowymi, a prototypami 
postaci $\mathrm{w}$ ich utworach są często prawdziwi ludzie. W przeciwieństwie do M. Matios D. Rubina stale przebywa $\mathrm{w}$ różnych narodowych obszarach kulturowych, doświadczając wpływu środowisk wielokulturowych i relacji międzykulturowych. Dlatego jako pisarka rosyjsko-izraelska wizualizuje ideę innych ludzi, innych kultur, używając znaczników narodowych. W analizowanych pracach autorki odnajdujemy cechy narodowościowe, w tym żydowskie i uzbeckie, związane z jej pochodzeniem i miejscem urodzenia. Twórczość M. Matios jest związana z ukraińskim komponentem narodowym i wyróżnia się tożsamością narodową i folkloryzmem. Porównanie i analiza lingwistycznego aspektu twórczości pisarek ukazały, że M. Matios używa dialektyzmów, folkloryzmów i tropów, a D. Rubina częściej żargonu, slangu oraz obscenicznego słownictwa.

Słowa kluczowe: dyskurs imagologiczny, „swój”, „inny”, „obcy”, obrazy narodowe, osobliwości narodowe, środki stylistyczne.

Пізнання світу відбувається через усвідомлення себе в порівнянні з кимось або чимось іншим. Д.-А. Пажо визначає роль художньої літератури як інструмента, провідника, який «прокладе шлях до глибокого розуміння сутності іншого» [Пажо 2011: 407]. Саме літературна імагологія поєднує в собі філологічні та культурологічні аспекти образів «чужої» культури або «іншої» нації. Науковець Л. Оляндер підкреслює складність характеру відносин «свого» і «чужого» і стверджує, що «сама природа цього явища вимагає розгляду різних форм їхнього вияву» [Оляндер 2011: 175]. Також одним із аспектів сучасної компаративної імагології є власний погляд на такі теми, як «інаковість митця, письменника, який створює власний імідж, далекий від загальноприйнятого, і сприйняття його різними групами людей» [Свербілова: 7]. Інтерпретація відносин «свого» та «чужого» відбувається, у першу чергу, через власне бачення автора художнього твору. У нашому випадку - через особисту думку, світогляд, творчий задум і досвід сприйняття «іншого» Марією Матіос $\mathrm{i}$ Діною Рубіною. Творчість цих письменниць пов’язана з темами, які їх хвилюють у житті, а прототипами їхніх персонажів є реальні люди, про що часто зізнаються самі авторки.

М. Матіос і Д. Рубіну як представниць сучасної жіночої художньої прози об’єднує зацікавлення національною темою, проблемою національних образів світу. Особливий інтерес становлять типологічні збіги та відмінності у візуалізації письменницями образів «свого» та «чужого», адже для імагології концепт «свої - чужі» є основоположним. Їхні авторські тексти створені майже рівночасно, вони подібні за жанром і стилем; мисткині слова належать до однієї літературної доби, оцінюючи минуле та сучасне як перетин «свого» та «чужого».

На сьогоднішній день твори української письменниці перекладені багатьма мовами і вийшли друком у Канаді, США, Хорватії, Сербії та Росії. Різновекторні дослідження творчості М. Матіос здійснювали Н. Бербер, О. Вірич, Ю. Кушнерюк, І. Насмінчук, Г. Павлишин, Д. Павличко, К. Хижняк, С. Філоненко та інші.

Життєпис і творчість цієї сучасної російсько-ізраїльської авторки досліджували Д. Зіятдінова, Г. Зуєва, А. Сільчева, Е. Шафранська та інші. 
Наукова новизна та актуальність статті обумовлена новизною самих понять «імагологічний дискурс», «літературна імагологія», відсутністю їхніх загальноприйнятих дефініцій. Вперше проза М. Матіос і Д. Рубіної стала предметом спеціальної наукової розвідки крізь призму імагологічного дискурсу та індивідуального авторського бачення протиставлення «свої - чужі» в їхніх творах.

Констатуємо, що в даний час у літературній імагології продовжується дискусія щодо науково обгрунтованих, загально визнаних методів дослідження художніх образів «іншого», «чужого». Саме тому використовувались елементи комплексного аналізу літературнохудожнього тексту, біографічного, порівняльно-історичного, зіставно-типологічного та герменевтичного літературознавчих методів, постколоніального підходу, які сприяли досягненню мети статті - проаналізувати специфіку індивідуального авторського бачення протиставлення «свої - чужі» в творах Д. Рубіної та М. Матіос.

Образ світу у творах Д. Рубіної - це наслідок діалогу між особистістю і реальністю, між особистістю і традицією, націями та культурами. Письменниця встановлює діалогічні відносини між «своїм» і «чужим». «Своє» пов’язане з духовним світом Д. Рубіної, а «чуже»3 іншою культурою, нацією. Образ «іншого», тобто не росіянина і не єврея, у творах письменниці індивідуалізований, багатогранний і динамічний. В основі сприйняття «іншого» лежить стереотип, сформований на підставі історичного досвіду. Констатуємо, що важливими ознаками стереотипів є образність, цілісність, символічність і суб'єктивність; етнічні стереотипи - категоричні, містять у собі як позитивний, так і негативний оціночні компоненти [Шевелева 2003: 73]. В основі стереотипу поєднуються описовість зовнішності та відверто фальшована характерологія, тобто найгірші прикмети конкретної людини чи народу, культури [Пажо 2011: 405-406]. Як зазначалося вище, так формується образ «чужого», який стереотипно сприймається представниками інших народів.

Д. Рубіна як письменниця пройшла становлення в білінгвальному та бікультурному середовищі: «С детства варясь в нашем Вавилоне этносов, наций и народностей, мы знали, что человек может быть другим, более того: что он всегда другой, но надо, надо сосуществовать, раз некуда друг от друга деться, что важнее всего - сосуществовать, что жизнь на этом стоит! И вот это самое умение понимать другого, как выяснилось в экстремальных условиях самых разных эмиграций, и есть - одно из лучших качеств человеческой натуры. То, что на Западе называют безликим словом “толерантность”. Да не толерантность это, а - вынужденное милосердие, просто-напросто смирение своего “я”, когда понимаешь, что ты не лучше другого, а он - не выше тебя» [Рубина 2004: 366].

Для Д. Рубіної важливо візуалізувати уявлення про інший народ, іншу культуру. Авто- та гетеростереотипи у творах Д. Рубіної пов'язані з уявленнями емігрантів і корінних ізраїльтян про себе та «чужих», тобто вихідців із СРСР. Персонажі їі творів, переїхавши до 
Ізраїлю, потрапляють у мультикультурне ізраїльське суспільство, членам якого, як зауважують дослідники, притаманна гібридна ідентичність, оскільки там співіснують представники різних субетносів [Козлов 2004].

Це слушне твердження можна проілюструвати іронічним описом пошуку ідентичності євреєм Фабриціусом, який вимушено шукає власне національне коріння:

«А есть еще у нас Фабрициус ван Браувер, очень милый. Огромный такой мужик, блондин. Голландский еврей. Причем то, что он - голландский, он знал, а то, что - еврей, узнал, когда шесть лет назад мама у него умирать стала $<\ldots>$ берет с него клятву после ее смерти отсидеть по закону “шиву” и сразу ехать в Израиль. Вот что на человека в один миг может обрушиться! Теперь вообразите невинного голландца перед лицом этих диких еврейских обстоятельств...

Он отсидел “шиву” и приехал, и ничего - живет. Ему нравится. Иврит только не осилил, все поанглийски. Сам здоровенный такой голландец, говорит: “Май фазер - гой...”

Он здесь работает охранником у Стены Плача» [Рубина 2011: 82].

Інколи персонажі творів Д. Рубіної не мають імені та прізвища (до прикладу, образи узбеків у романі «На солнечной стороне улицы»), тому що для авторки важливішою є національна приналежність іiі героїв, аніж їхня точна «ідентифікація». Письменниця із симпатією зображає представників різних національностей, тобто «інших» по відношенню до євреїв. Проте, в її творах зустрічаються «інші» як «чужі», зловісні, такі, що несуть загрозу для життя - зокрема араби.

Сама письменниця вживає термін «національне самопочуття», який об'єднав різні почуття у певну гібридну сутність: «Це може бути і почуття причетності до народу, й почуття гордості, і почуття відштовхування, огиди... - в залежності від того, якою “стороною обличчя” до тебе твій народ повертається. Я пишу про різні боки характеру мого народу, пишу без зворушливості, часто з гіркотою (письменник зобов’язаний говорити правду), але, тим не менше, пишу з любов'ю - і було би дивно, якби писала без любові, адже я здорова людина» [Рубина 2008].

Національний егоцентризм у творах Д. Рубіної не завжди виявляється в такому відкритому вигляді. Досить часто він існує у прихованому - «розчиненому» або «напіврозчиненому». Ідентифікаційні маркери національних характерів прослідковуються в усіх проаналізованих нами творах письменниці. Також, не можемо не погодитися 3 Ю. Павловим, котрий вважає, що Д. Рубіна «наполегливо проводить думку: євреї - ось народ, який абсолютно перевершує всіх інших за своїми професійними чи людськими якостями» [Павлов 2008].

На наше переконання, Д. Рубіна у своєму становленні професійної письменниці відчула на собі проблему самоствердження та сміливо пройшла шлях національної самоідентифікації. Це простежуємо через роздуми героїні аналізованого вище оповідання 
«Яблоки из сада Шлицбутера», де авторка пропонує собі шукати відповідь на питання «чия я, чия?» в сокровенному почутті «со-крови» (sic!). Авторське почуття «со-крови» розглядаємо як прояв національного егоцентризму, який опосередковано пов'язаний 3 переслідуванням власного народу та самоідентифікацією, яка не обмежена в часі.

На відміну від Д. Рубіної, тексти творів М. Матіос вирізняються не так національним егоцентризмом, як насамперед національною самобутністю та колоритною фольклористичністю. У творчості письменниці можна простежити традиційні та постмодерністські тенденції, «оскільки в ній відбився характер стильових течій кінця ХХ початку XXI століть: нестійкість і суперечність буття, криза свідомості, українського духу, релігії та віри» [Павлишин 2012: 8]. Стиль М. Матіос вирізняється метафоричністю й естетичною довершеністю мовлення. Ї̈̈ персонажі часто виступають втіленням справжньої людини - доброї, люблячої, з вірою в душі, порядної. Вони протистоять «іншим» - ворожим, тим, що несуть зло і загрозу. На думку літературознавиці Г. Павлишин, «новаторство М. Матіос полягає у тому, що вона принесла власне бачення архетипного образу в сучасний постмодерністський канон, зокрема глибше за своїх попередників і сучасників розуміє та відтворює міфологічні й фольклорні символи, демонструючи при цьому баланс земного / небесного, фізичного / духовного, стереотипного / неповторного. Тому фікційні тексти письменниці разом із творами українських класиків є неоціненним джерелом духовного збагачення сучасних читачів» [Павлишин 2012: 9].

Тлом подій у творах із збірки «Вибране» М. Матіос, зокрема у «Солодкій Дарусі», слугує буковинське село, а головні персонажі - це його мешканці, які ніби існують поза часом i поза простором. Структурування рустикального хронотопу засвідчує увагу письменниці до опису сталості традицій, над якими не підвладний час і простір: «По два боки мілкого навесні і повноводого влітку, але незалежно від пори року, завжди гомінкого i спішного Черемоша, між горбів і кичер, немов у глибокій жіночій пазусі, гніздилися двоє гірських сіл з однаковою назвою - Черемошне. Коли б можна було дивитися на них з висоти пташиного польоту чи хоча би із середини ріки, то села відбивалися між собою так само однаково, як відбивається людське обличчя у дзеркалі. Споконвіків мешканці обидвох Черемошних говорили майже однаковою материнською мовою, і однаково складали руки до однакового “отченашу”, в один і той же день святкували Різдво і Великдень, і навіть одяг у них був схожий, і клятьби, і подяки, лиш віталися люди по два боки ріки трохи інакше, ото майже і вся різниця. [Матіос 2010: 146].

3 огляду на концепцію «пограничної людини» письменниця здійснює поділ на «своїх» та «чужих». Так, у романі «Солодка Даруся» «чужими» для місцевого населення стають, у першу чергу, представники окупаційної влади - досі незнані німці та більш знайомі румуни. Авторка зауважує тривкість негативних стереотипів, пов'язаних із конфліктами між 
румунами та буковинцями в минулому, тому у творі підкреслюється часткове несприйняття німецьких і румунських окупантів місцевими жителями: «

Німці стояли в селі недовго і великої шкоди людям не зробили, так само як черемошнянські люди не робили шкоди і їм, хіба що біданка Анниця, яка роками слабувала на голову, ходила по селу із запаленим на кінці тички ганчір'ям $<\ldots$. .

Ti самі, що й до війни, а може, ще гірші, грубі свинські постоли нової-старої румунської адміністрації дуже дисонували з наваксованими чоботами зниклого німця, але в Черемошному бачили й не таке: чи один маєтний газда нерідко брав собі за союзника злидоту, аби лише мати на селі більший вплив, а швидше, чисту фізичну силу. Новими-старими порядками були ті самі, а подеколи, іще пекучіші букові палиці, та тепер уже повсюдні й категоричні заборони будьяких політикувань» [Матіос 2010: 166].

М. Матіос у своїх численних інтерв’ю стверджує, що іiї творчість грунтується на виразному національному компоненті. «Найвищий духовний авторитет митця, на мою думку, - констатує письменниця, - це однозначне позиціонування його як митця національної традиції» [Таран 2006: 5]. Також авторка підкреслює, що вона тісно пов'язана 3 біографією свого роду та краю: «Усі трансформації, які відбуваються в мені, моєму світогляді, оцінках тощо, зав’язані винятково на моїх горах, на гуцульській Буковині» [там же]. На нашу думку, це зізнання знайшло повне відображення в іiі творах, зокрема, у згадуваній вище збірці «Вибране». Звідси особливості дискурсу мови творів М. Матіос, для якої притаманні індивідуальні художні елементи мовлення, а саме діалектизми, зокрема: копинь - стара назва вересня, просинець - стара назва грудня, набуток - весілля, файкувати курити, мольфарити - чаклувати, шляхтувати - проклинати, шпік - мозок, зведениця покритка, дріб - вівці, шульок - качан, первий - двоюрідний, канони - гармати, пужати лякати, верстак - ровесник, колітка - замок та ін. Як справжній знавець та поціновувачка народних традицій і звичаїв М. Матіос постійно використовує художні тропи, взяті 3 фольклору, просторічні слова та вислови, приказки, прислів'я, народні символи, афоризми та елементи народної мудрості, наприклад: «очі-звізди»; «як ангел, чистий»; «поплакалапослинилася»; «гриз зубами камінь»; «про людське око»; «щезла би’сь у болото»; «як ведмідь у малинах»; «вона здорова - як цвях»; «мачуха - не хліб пшеничний»; «однакові як три каплі води»; «обернути язик навиворіт»; «язик не мав стриму між зубами»; «шукати пригоди на свою голову»; «ріже словами, ніби ножами»; «вривати собі серце плачами»; «крутить капелюх, щоб голова боліла дужче»; «надокучливий хробак точить серце»; «лютий, як справжня йорданська студінь»; «ведмеді би були його роздерли»; «яке їхало - таке здибало» тощо. Зауважимо, що вони характеризують персонажів і допомагають письменниці висловити різні почуття та ставлення, зокрема до «іншого», «дивного», «чужого».

Оскільки мова є одним із засобів опису художнього світу, виявом внутрішньої 
культури та етнічної приналежності персонажів, Д. Рубіна, як і М. Матіос, 3 метою увиразнення мовлення використовує національні маркери. Проте у Д. Рубіної вони також спрямовані в іншомовну культуру і слугують дієвим засобом міжкультурної комунікації. Зокрема, у романі «Почерк Леонардо» з такою метою використовуються українізми: «Йдыно сюды! - повторила Христина. - Ликуваты тэбэ будэмо...», «Така ж вэсэла гра! Стий, не рухайся! Зараз будэ в нас полчеловека!» [Рубина 2013: 46], «Тю! От лялька!» [там же: 49], «Усе можеш! - крикнула Христина. - Брешеш, можэшь!» [там же], «Трымай! Назад нэ поидэмо!... Боженька терплячих полюбляе!» [там же: 51-52].

Слід акцентувати увагу на використанні жаргонізмів, сленгізмів, обсцентної лексики як мовної особливості художніх текстів Д. Рубіної, наприклад: «жив-здоров», «отчаянный брехун», «пропится до штанов», «физиономия», «я плюю на тебя», «черножопые», «вытаращеные бельма с точками злющих зрачков», «изящный ротик распахивался в пасть», «воронок», «главное, ни хрена не бойся», «нет куража», «хана делу, веники», «серые, тусклые, бритоголовые рожи», «набыченые глаза», «зал... набитый серо-черными ватниками», «черт возьми», «черт бы ее побрал», «грабанет половину гонорара», «насобачился в этом деле», «А тебя это гребет?», «я пережил Гитлера, лагерных вертухаев и целую банду уголовной шпаны», «Опять накиррялся? Как свинья!» [Рубина 2005: 27]. Д. Рубіна, $з$ метою надання комізму певній ситуації, свідомо «ламає» російську мову узбецького місцевого населення: «Урок иду... Умирайт хочу... Мой “джаляб” такой злой! У мне от страх перед каждый занятий дрисня...» [там же: 59]. Славіст О. Ларіонова називає введення в текст запозичених слів Д. Рубіною «загальмуванням», оскільки це дає особливу яскравість рядкам, які мають особливу важливість і які вимагають від читача певної паузи для роздумів над прочитаним текстом. Це спостереження науковця стосується роману «Вот идёт Мессия!..», однак, на нашу думку, його можна поширити на всю прозову творчість письменниці, особливо для візуалізації образу «іншого» та «чужого» [Ларионова: 13].

Тлом для подій, які увиразнюють інакшість персонажів, в творах обох письменниць також слугують реальні історичні факти. У М. Матіос - це межа зіткнення місцевого населення з окупантами та національно-визвольна боротьба в Західній Україні 30-50-х рр. минулого століття, а в Д. Рубіної - історії переслідувань єврейського народу в різні часи.

М. Матіос підкреслює, що мешканці Буковини постійно страждають від змін влади румунської, австро-угорської, німецької i, найбільше, радянської. Для персонажів у творах української письменниці чужорідними, тобто тими, що несуть небезпеку, загрозу життю українців Буковини, були представники окупаційної влади. Авторка стверджує, що найбільше зло принесла на землі Західної України радянська влада, яка не зважала на інтереси та потреби місцевого населення, застосовувала жорстокий терор. На думку М. Матіос, тогочасна трагедія українського народу пов'язана з такою особливістю української 
ментальності, як індивідуалізм. Звідси - відсутність колективного протистояння «іншому», «чужому». Ось чому кожен буковинець у творах письменниці вирішує самостійно, як йому діяти - чи протистояти, чи залишатися безмовним спостерігачем. Також письменниця не оминає увагою й фактів співпраці з окупантами й зради своїх побратимів по боротьбі: «Давно минув той час, коли бункери копали по лісах. У лісі, після десятка-другого облав, бункерів лишилося стільки, що пальців одної руки буде забагато, щоб їх перерахувати. Надворі стоїть 1950-й рік. По лісах лишилися найзапекліші. Інших - виловили. Ще інших - iз примусу чи зі слабкості продали вчорашні свої. Одних - постріляли. Других - заслали в тюрми чи в Сибіри. Дехто, кажуть, прорвався за кордон, дехто - правдами-неправдами легалізувався в новому житті, чекаючи слушного моменту, щоби знову витягнути гвери. Хоча на те надії мало. Та залишалася жменя камінних, як їх назвав одного разу друг “Береза”. Корнелія належала до цісї камінної жмені» [Матіос 2010: 244].

У відвертих роздумах про своє життя на Буковині, М. Матіос наголошує, що цей історичний регіон - мультикультурний та поліетнічний, тож специфіка рідного краю навчила iї «толерантності до всіх, хто інший, інакший від тебе. Але навчили також, що кожна людина - незалежно від мови, віри, світогляду - має свою правду і своє алібі, а також має законне i природне право зберігати свою ідентичність за найнесприятливіших умов» [Матіос 2011: 30].

Отже, спільною рисою особливостей художніх текстів М. Матіос і Д. Рубіної є передача місцевого колориту, традицій, мовлення певного регіону, що безпосередньо пов'язано з автобіографізмом їхніх творів. Знання усної народної творчості, мови, звичаїв, культури та вірувань українців Буковини допомогли М. Матіос правдиво відтворити на сторінках творів історичну минувшину на межі зіткнення різних політичних систем, взаємини «своїх» та «інших», «чужих». Так, письменниця використовує діалект як художній мовностилістичний засіб, який допомагає читачам познайомитися з реаліями повсякденного життя буковинців. Діалектизми, просторічні слова, фольклорні i художні тропи та стилістичні фігури передають i широкий спектр почуттєвої сфери - співчуття або захоплення, зневагу та обурення персонажів творів. Використання жаргонізмів, сленгізмів, обсцентної лексики, запозичень трактуємо як мовну особливість художніх текстів Д. Рубіної. Вони відображають роздуми та переживання, долучають до творення неповторного авторського погляду на світ, який простежуємо у фікційних текстах письменниці. Д. Рубіна на тлі кривавих історичних подій, пов’язаних із переслідуваннями єврейського народу, розкриває проблематичні відносини «своїх» та «чужих». Таку саму проблематику окреслює $\mathrm{i}$ М. Матіос - щоправда, вже на українському, точніше - буковинському, матеріалі.

\section{ЛІТЕРАТУРА}

Козлов, Ю. (2004), Проблема национальной/этнической идентификации в творчестве Дины Рубиной.
Literature
= Лuтература.
No
46
(2).
1-16.
URL: 
http://www.journals.vu.lt/literatura/article/view/8201/6072 (20.12.2019) [Kozlov, Yu. (2004), Problema natsional'noy/etnicheskoy identifikatsii v tvorchestve Dini Rubinoy. Literature = Literatura. No 46 (2). $1-16$.$] .$

Ларионова, Е. Заимствования как фундаментальный языковой приём в прозе Рубиной (Роман «Вот идёт Мессия!..»). URL: http://siba-ese.unisalento.it/index.php/linguelinguaggi/article/viewFile/12640/11251 (25.01.2020) [Larionova, E. Zaimstvovaniya kak fundamental'niy yazikovoy priem v proze Rubinoy (Roman "Vot idet Messiya!..")].

Матіос, М. (2010), Вибране. Львів [Matios, М. (2010), Vibrane. Lviv].

Матіос, М. (2011), Вирвані сторінки з автобіографії. Львів [Matios, M. (2011), Virvani storinki z avtobiografii. Lviv].

Оляндер, Л. (2011), Форми вияву імагологічних процесів у суспільстві й у літературі та способи їх відображення у творах письменників. Волинь філологічна: текст і контекст. Вип. 12. 175-182 [Olyander, L. (2011), Formi biyavu imaholohichnikh protsesiv u suspil'stvi y u literaturi ta sposobi yikh vidobrazhennya u tvorakh pis'mennikiv. Volin'filolohichna: tekst i kontekst. Vip. 12. 175-182].

Павлишин, Г. Я. (2012), Дискурс прози Марії Матіос: дис. ... канд. філол. наук. Чернівці [Pavlishin, H. Ya. (2012), Diskurs prozi Mariyi Matios: dis. ... kand. filol. nauk. Chernivtsi].

Павлов, Ю. (2008), Дина Рубина: портрет на фоне русскоязычных писателей и Франца Кафки. Наш современник. № 11. 271-280. URL: http://www.rospisatel.ru/pavlov-rubina.htm (04.03.2016) [Pavlov, Yu. (2008), Dina Rubina: portret na fone russkoyazichnikh pisateley i Franza Kafki. Nash sovremennik. No 11.271-280.].

Пажо, Д.-А. (2011), Від культурних кліше до імажинарного. Літературна компаративістика. Вип. IV: Імагологічний аспект сучасної компаративістики: стратегї̈ та парадигми. Ч. ІІ. Київ. 396430 [Pageaux D.-H. (2011), Vid kul'turnikh klishe do imazhinarnoho. Literaturna komparativistika. Vip. IV: Imaholohichniy aspekt suchasnoyi komparativistiki: stratehiyi ta paradihmi. Ч. II. Kyiv. 396-430].

Рубина, Д. (2004), Синдикат: роман-комикс. Москва [Rubina, D. (2004), Sindikat: roman-komiks. Moskva].

Рубина, Д. (2005), Камера наезжает!.. Москва [Rubina, D. (2005), Kamera naezzhaet!.. Moskva].

Рубина, Д. (2008), Мы не в проигрыше. Нева. № 12. 180-188 [Rubina, D. (2008), Mi ne v proigrishe. Neva. No 12. 180-188].

Рубина, Д. (2011), Двойная фамилия: рассказы. Москва [Rubina, D. (2011), Dvoynaya familiya: rasskazi. Moskva].

Рубина, Д. (2013), Почерк Леонардо: роман. Москва [Rubina, D. (2013), Pocherk Leonardo: roman. Moskva].

Свербілова, Т. Іміджі та міражі радянського літературного проекту в аспекті імагологічних студій. Academia.edu. URL: https://independent.academia.edu (16.01.2020) [Sverbilova, T. Imidzhi ta mirazhi radyans'koho literaturnoho proektu v aspekti imaholohichnikh studiy. Academia.edu].

Таран, Л. (2006), Марія Матіос: «Завжди має бути щось інше». Вечірній Київ. 7 квітня. 5 [Taran, L. (2006), Mariya Matios: „Zavzhdi maye buti shchos’ inshe”. Vechirniy Kiyiv. 7 kvitnya. 5].

Шевелева, И. П. (2003), Этнический стереотип как феномен культуры. Культура народов 
Причерноморья. № 37. 72-76 [Sheveleva, I. P. (2003), Etnicheskiy stereotip kak fenomen kul'turi. Kul'tura narodov Prichernomorya. No 37. 72-76]. 